PATTINGALLOANG

(C) Jurnal Pemikiran Pendidikan dan Penelitian Kesejarahan

\title{
Pemerintahan Danny Pomanto di Makassar, 2014-2018
}

\author{
Azrianti $^{1}$, Amirullah $^{2}$ \\ 'Program Studi Pendidikan Sejarah Fakultas Ilmu Sosial UNM \\ 'azriantinasaruddin@yahoo.com, ${ }^{2}$ amirullah8505@unm.ac.id ${ }^{2}$
}

\begin{abstract}
Abstrak
Penelitian ini bertujuan untuk mengetahui bagaimana kondisi awal pemerintahan Danny Pomanto, bagaimana pelaksanaan kebijakan-kebijakan dari Danny Pomanto dalam mengembangkan Kota Makassar tahun 2009-2014 dan tahun 2014-2018, dan bagaimana dampak kebijakan pemerintahan Danny Pomano di Kota Makassar. Hasil penelitian menunjukkan bahwa kondisi Kota Makassar sebelum pemerintahan Danny Pomanto memiliki permasalahan yang perlu di tangani baik itu di bidang pendidikan, bidang infrastruktur dan pembangunan, bidang kesehatan dan bidang ekonomi. Pada periode awal Danny Pomanto memerintah dilakukan berbagai gerakan seperti Gerakan Makassar Bersih (Lisa). Penelitian ini bersifat desktiptif analisis dengan menggunakan metode historis melalui tahapan: heuristik atau pengumpulan data, kritik, interpretasi, dan tahap penulisan atau historiografi
\end{abstract}

Kata Kunci: Pemerintahan, Dampak, Kebijakan dan Makassar

\begin{abstract}
This study aims to determine how the initial conditions of the administration of Danny Pomanto, how the implementation of policies from Danny Pomanto in developing Makassar City in 2009-2014 and 201 42018, and how the impact of Danny Pomano's government policies in Makassar City. The results showed that the condition of Makassar City before the administration of Danny Pomanto had problems that needed to be addressed either in the fields of education, infrastructure and development, health and the economic sector. In the early period Danny Pomanto governed various movements such as the Makassar Clean Movement (Lisa). This research is a descriptive analysis using historical methods through stages: heuristics or data collection, criticism, interpretation, and writing or historiography stages.
\end{abstract}

Keywords: Governance, Impact, Policy and Makassar

\section{A. Pendahuluan}

Sulawesi Selatan dengan dominasi suku BugisMakassar, juga memiliki pandangan terhadap berjalannya sebuah kepemimpinan.Konteks pemerintahan orang Bugis-Makassar dengan menganut tata nilai budaya Bugis-Makassar melihat bahwa sebuah kepemimpinan harus mengutamakan tata nilai etika dan moralitas politik. Sejak era la galigo sampai masuknya Islam di Sulawesi Selatan telah melahirkan banyak pemimpin-pemimpin dengan kualitas moral yang mumpuni. Kualitas moral terakumulasi dalam kearifan lokal yang dikenal dengan sipakatau (memanusiakan manusia). Dalam hal ini Walikota Makassar sebagai pemimpin politik hendaknya memiliki visi untuk masa depan kota Makassar dengan mempertahankan nilai etika serta moralitas dan mengembangkan kearifan lokal Bugis-Makassar.

Perkembangan kota besar di Indonesia menyimpan segudang masalah rumit. Dari mulai soal infrastruktur, transportasi, penggunaan energi dan air sampai menyangkut penyakit kronis efesiensi birokrasi. Makin tahun permasalahan kota tersebut cenderung semakin kompleks.sedangkan sumber daya dan akan semakin terbatas.

Merujuk pada rangkaian pemilihan Walikota Makassar tahun 2013 (pilawlkot Makassar 2013), pasangan Mohammad Ramdhan Pomanto-Syamsu Rizal (DIA) mendapatkan kesempatan memimpin Kota Makassar selama 5 tahun (2014-2019). Melalui pemilihan yang dilakukan langsung oleh masyarakat Makassar, bahwa tercatat pasangan 
DIA meraih persentase hasil suara sebanyak 31,17 $\%$ (persen) atau 182,424 suara. Hasil perolehan suara tersebut, menjadikan DIA sebagai pemimpin politik dan pemerintahan di kota Makassar dalam lima tahun. Keberlangsungan kepemimpinan politik sendiri dapat dilihat sebagai kepemimpinan yang berlangsung dalam suprastruktur politik (partai politik dan organisasi kemasyarakatan).Sehingga, kepemimpinan DIA dalam lembaga pemerintahan dapat dilihat sebagai sebuah kepemimpinan politik.

Masa kepemimpinan Mohammad Ramdhan Pomanto - Syamsu Rizal ditandai dengan komitmennya, yakni "Mewujudkan Makassar kota dunia yang nyaman untuk semua. Kepemimpinan politik Mohammad Ramdhan Pomanto dalam beberapa (Kusuma, 2018) tahun terakhir mencoba mengangkat derajat masyarakat lorong dikota Makassar. Mengingat semasa kampanye, tagline ana' lorongan Makassar menjadi salah satu elemen penting dalam menghantarkannya menjadi Walikota Makassar.

Penelitian ini lebih berfokus kepada pemerintahan Danny Pomanto di Makassar secara umum, dimana membahas kondisi awal pemerintahan Danny Pomanto, pelaksanaan kebijakan-kebijakan dari Danny Pomanto dalam mengembangkan Kota Makassar tahun 2009-2014 dan tahun 2014-2018, dan bagaimana dampak kebijakan pemerintahan Danny Pomano di Kota Makassar. Berbeda dengan penelitian sebelumnya dengan judul kepemimpinan Danny Pomanto di Kota Makassar yang ditulis oleh Olan Nur Rakhmat Johansyah. yang berfokus kepada proses analisa gaya kepemimpinan politik Danny Pomanto sebagai Walikota Makassar, serta menggambarkan implikasi dari gaya kepemimpinan politik Danny Pomanto terhadap respon masyarakat lorong di Kota Makassar.

Kepala daerah yang dipilihan oleh DPRD menimbulkan masalah ketika masih dalam prosesnya. Banyak asumsi bahwa pemilihan kepala daerah yang melalui anggota DPRD sebagai lahan "bisnis" bagi anggota DPRD dan calon Kepemimpinan secara umum melihat bahwa, kepemimpinan yang efektif merupakan kepemimpinan merujuk kepada hasil, bukan kepada pidato maupun atribut yang dikenakannya. Sedangkan dalam politik, sebuah kepemimpinan politik tersebut mengemas kepemimpinannya dalam bentuk dominasi, yang sanggup mempengaruhi orang lain dengan menggunakan atribut kepemimpinannya. Kepercayaan, nilainilai, sifat, pengetahuan, dan keterampilan, merupakan atribut yang digunakan pemimpin untuk melakukan dominasnya terhada pihak yang ingin dipengaruhi. Sehingga, aktor politik akan berusaha menggunakan atribut tersebut dalam menajalankan maupun merebut kursi kepemimpinan politik. (Temmanengnga M. G., 2014)

Danny Pomanto yang resmi dilantik pada tanggal 8 Mei 2014, yang juga resmi memiliki hak serta tanggung jawab sebagai kepala daerah kota Makassar hingga berakhirnya masa jabatannya sebagai pemimpin politik. Danny Pomanto merupakan arsitek professional, Danny Pomanto sebagai arsitek professional dapat dilihat dari hasil karyanya, masjid amirul mukminin merupakan salah satu hasil karya arsitek yang juga merupakan mantan dosen arsitektur di Universitas Hasanuddin (UNHAS) Makassar. (Temmanengnga, 2014)

\section{B. Metode Penelitian}

Penelitian tentang Pemerintahan Dani Pomanto di Makassar 2004-2018 ini termasuk jenis penelitian sejarah, yaitu sejarah daerah, sejarah pemerintahan, dan sejarah tokoh. Dalam melakukan penelitian sejarah ada metode, jalan, cara, atau prosedur yang mesti dilakukan oleh seorang peneliti. Tanpa metode, kumpulan pengetahuan tentang objek tertentu tidak dapat dikatakan sebagai ilmu. Dalam kaitannya dengan ilmu sejarah, dengan sendirinya metode sejarah ialah "bagaimana mengetahui sejarah". (Sjamsuddin, 2012)

1. Heuristik

Heuristik merupakan pengumpulan sumber. Untuk memperoleh sumber atau data yang valid dan akurat, maka sangat diperlukan tehnik pengumpulan data yang baik, benar dan tepat (no document no history). Dalam penelitian ini tehnik yang akan digunakan untuk mengumpulkan data, dan untuk memperoleh data maka dilakukan dengan cara penelitian pustaka dan penelitian lapangan dan melakukan proses wawancara dengan Danny Pomanto secara Langsung.

a. Penelitian Pustaka (Library Research)

Pengumpulan sumber sejarah dengan motode kajian keperpustakaan. Dalam hal ini 
penulis melakukan penelitian pustaka dengan cara mengkaji beberapa sumber yang terkait kegiatan penelitian dengan mengumpulkan data dan fakta-fakta sejarah dengan cara mengkaji dan menelaah karya tulis, buku-buku yang didapatkan pada perputakaan umum UNM, Perpustakaan Prodi Pendidikan Sejarah, Perpustakaan Kota Makassar, Kantor Walikota, Balai Kajian, Perpustakaan Multimedia, Departemen Agama Kota Makassar, dan Departemen Sosial Kota Makassar, serta instansi yang terkait dengan objek penelitian.

b. Penelitian Lapangan

Penelitian lapangan dilakukan dengan cara mendatangi langsung di lokasi khusunya mereka yang ikut berperang aktif dalam pemerintahan yang ingin di kaji. Dalam penelitian lapangan penulis menempuh dua cara yaitu obsevasi, wawancara dan dokumentasi.

\section{1) Observasi}

Pengamatan langsung terhadap objek yang diteliti. Dalam hal ini penulis melakukan observasi di Kota Makassar secara langsung guna mendapatkan gambaran, seperti kegiatan yang berlangsung pada kantor pemerintahan Balai Walikota Makassar dan hasil-hasil pembangunan yang jelas tentang perkembangan Kota Makassar pada pemerintahan Dani Pomanto (2004-2014).

b) Wawancara

Teknik pengumpulan data dengan mengadakan tanya jawab kepada orang-orang yang dianggap mengetahui peristiwa yang akan dikaji. Wawancara dilakukan terhadap orangorang yang terlibat dalam kaitannya dengan masalah yang dibahas. Wawancara dengan Danny Pomanto, beberapa staf pemerintahan, dan orang yang mampu memberikan informasi maupun data tambahan Misalnya tokoh masyarakat atau masyarakat umum.

c) Dokumentasi

Dokumentasi, adalah kegiatan pengumpulan data dengan mengumpulkan data berupa dokumen seperti: keputusan-keputusan, suratsurat, LPJ, RAPBD, gambar, dll. Yang berkenaan dengan arsip-arsip yang terkait dengan Makassar pada masa pemerintahan Dani Pomanto dan data-data yang relevan dengan objek kajian.
Kritik Sumber dilakukan untuk menentukan otensititas dan kredibilitas sumber sejarah. Semua sumber yang telah dikumpulkan terlebih dahulu diverifikasi sebelum digunakan. Sebab tidak semua sumber bisa langsung digunakan dalam penulisan. Adapun aspek yang dikritik ialah keaslian sumber dan tingkat kebenaran informasi. Dalam metode sejarah dikenal dengan cara melakukan kritik eksternal dan kritik internal.

3. Interpretasi

Interpretasi yaitu proses menyusun, merangkaikan antara satu fakta sejarah dengan fakta sejarah lain, sehingga menjadi satu kesatuan yang dapat dimengerti dan bermakna. Interpretasi berarti menafsirkan, menganalisa, serta menggabungkan fakta-fakta sejarah yang telah didapatkan. "fakta-fakta itu merupakan lambang atau wakil dari pada sesuatu yang pernah nyata ada, tetapi fakta ini tidak memiliki kenyataan objektif sendiri. Dengan kata lain faktafakta itu hanya terdapat dalam pikiran pengamat atau sejarawan. Karenanya disebut objekktif, yakni tidak memihak sumber, bebas dari seseorang, sesuatu pertama kali dia harus mempunyai eksistendi yang merdeka”. (Hamid, 2011)

4. Historiografi

Setelah menyelesaikan serangkaian tahap pertama, kedua, dan ketiga, maka tahap terakhir yakni penyajian atau penulisan yang disebut historiografi. Ketika sejarawan memasuki tahap menulis, maka ia mengerahkan seluruh daya pikirannya, bukan saja keterampilan teknis penggunaan kutipan-kutipan dan catatan-catatan, tetapi yang utama penggunaan pikiran-pikiran kritis dan analisisnya dari seluruh hasil penelitiannya atau penemuannya dalam suatu penulisan utuh. Sehingga menghasilkan suatu karya tulis yang mampu mempunyai nilai yang berguna dan bermanfaat bagi pembaca di kalangan akademik.

Hasil penulisan tersebut merupakan hasil dari penemuan sumber-sumber yang di seleksi melalui kritik yang baik ekstren maupun intern, secara deskriptif kemudian diinterpretasikan lalu disentesa yang selanjutnya disajikan.

\section{Kritik Sumber}

\section{Tinjauan Penelitian}

Vol. 7, No.1 April 2020, 74-88 | 81 
Adapun sumber referensi yang di temukan terkait danny pomanto dalam rekaman sejarah Makassar yang di tulis oleh adi suryadi culia, zainuddin tika, muh. Amir merupakan sumber untuk Makassar menuju kota dunia Hal yang menarik dari judul ini adalah bagaimana sosok seorang Danny yang mampu memimpin Makassar telah menunjukkan bahwa sosok Danny adalah sosok walikota yang berhasil mengembangkan Kota Makassar dan kemudian mendapat kepercayaan masyarakat. Beberapa kebijakan yang dikeluarkan juga dianggap efektif dalam pengembangan Kota Makassar. Salah satunya adalah kebijakan Danny tentang menggebrak lewat upaya membangun dari bawah dan membangun dari atas yaitu standarisasi pelayanan publik. melihat kondisi Kota Makassar yang semakin semrawut terutama dengan penangan sampah yang seperti sudah menjadi penyakit menahun menjadi bidikan pertamanya dengan program membangun lorong-lorong menuju kota dunia. (Idrus, 2005) Danny mengajak seluruh elemen masyarakat untuk tidak tinggal diam dalam memerangi sampah dengan pola hidup sehat.

\section{Hasil dan Pembahasan}

1. Kondisi Kota Makassar Pada Awal Pemerintahan Danny Pomanto.

Jika sejarah perjalanan Kota Makassar ditelusuri, maka akan ditemukan fakta-fakta sejarah masa silam dimana kota ini diera Pemerintahan VOC Hindia-Belanda menjadi pusat niaga dan transito di dunia timur. Ketika Makassar menyandang peran tersebut, saudagar dari penjuru dunia silih berganti datang berlabuh di Makassar untuk melakukan transaksi perdagangan. Membawa barang dari luar, kemudian membeli atau barter dengan barang lokal termasuk rempah-rempah dan hasil bumi, perjalanan waktu kemudian menunjukkan peran selaku kota niaga dan transito secara perlahan mengalami masa-masa surut dan suram. Dan pelabuhan niaga kemudian berpindah ke wilayah lain akibatnya masa-masa kejayaan itu akhirnya tinggal menjadi catatan sejarah.

Danny kemudian melakukan langkah Awal dengan cara mempertimbangkan dan menganalisa isu dan kecendrungan strategis yang sifatnya jangka panjang guna mencapai keberhasilan dari setiap usahanya. Mengingat kekuatan yang dimiliki oleh Kota Makassar adalah:

a. Jumlah sumber daya manusia yang cukup memadai.

b. Letak geografls wilayah yang sangat strategis dan sebagai ibu kota propinsi.

c. Potensi sumber daya alam, khususnya kelautan dan perikanan yang memadai. 4 . Tersedianya infrastruktur sosial ekonomi yang memadai.

d. Potinsi usaha perdangangan dan jasa yang memadai.

e. Potensi modal transportasi yang memadai. Dan

f. Suasana politik yang, stabil dan kearifan sosial yang berakar pada nilai-nilai budaya dan agama yang kuat. (Makasssar, 2015)

Program selanjutnya yang dilakukan oleh

Danny diawal Pemerintahannya adalah penyelesaian masalah pedagang kaki lima dan masalah pemukiman liar yang merupakan masalah warisan dari pendahulunya. Memang dua masalah ini merupakan dua masalah yang sulit untuk dicari penyelesaiannya. Tidak jarang pula tindakan yang diambil seringkali mendapatkan perlawanan baik itu dari aktivis dan masyarakat itu sendiri. Namun oleh Walikota Danny, kedua masalah ini diatasi dengan mengeluarkan peraturan yang bisa dianggap tegas dalam penetapannya. Meskipun sekali lagi tindakan itu tidak pelak mendapatkan banyak sorotan, namun Walikota tetap dengan pendiriannya. Masalah pemukiman liar yang ada di daerah Pannambungan dan Lette misalnya, dapat diatasi dengan mengeluarkan program pembuatan rumah susun (Rusun) bagi masyarakat yang harus digusur dari pemukimannya. Sedangkan masalah pedagang kaki lima, diawal Pemerintahannya Danny harus menghadapi masalah tersebut di dua tempat berbeda yang memang dipenuhi pedagang kaki lima yakni di jalan Metro Tanjung Bunga dan pedagang kaki lima yang ada disekitar pelabuhan. Namun kedua masalah ini bisa diselesaikan dengan jalan mediasi antara pihak pedagang dan Pemerintah beserta pihak yang terkait.

Program yang paling penting yang dilakukan oleh Danny adalah program revitalisasi Pantai Losari. Program besar yang menelan biaya yang tidak main-main itu yakni sekitar Rp. 104 miliar 
PATTINGALLOANG

(C) Jurnal Pemikiran Pendidikan dan Penelitian Kesejarahan

dilakukannya dalam rangka mencegah Pantai Losari dari kerusakan akibat abrasi yang terus terjadi di kawasan tersebut. Program ini dianggap perlu mengingat bahwa Pantai Losari merupakan salah satu Land Mark dari Kota Makassar. Revitalisasi sendiri merupakan upaya menghidupkan kembali suatu kawasan atau bagian kota yang dulunya pernah vital atau hidup akan tetapi mengalami kemunduran atau degradasi. (Haniah, 2011)kegiatan ini sendiri sejalan dengan gerakan Makassar Bersih yang memang menjadikan Pantai Losari sebagai kawasan percontohan peluncuran program F8 yang di adakan pameran Festival kebudayaan di pantai Losari ini oleh Walikota Danny. Itulah program yang dilakukan diawal Pemerintahannya. Selanjutnya hal itu akan lebih dibahas dalam pembahasan beriktunya.

2. Visi, Misi dan Strategi

Periode awal kepemimpinan Danny sebagai Walikota Makassar diwarnai oleh beberapa kebijakan yang dianggap otoriter dan melahirkan berbagai hujatan dan kritikan. Akan tetapi, tidak sedikit juga masyarakat yang mengakui kepemimpinan Danny. Awal, program pembangunan berkesinambungan; kedua, program pembangunan berkarakter yang dikemas dalam satu visi: "Makassar Kota Dunia Berlandaskan Kearifan Lokal" merupakan kesinambungan visi jangka panjang Kota Makassar tahun 2005-2025: "Makassar Sebagai Kota Maritim, Niaga, Pendidikan, Budaya dan Jasa Yang Berorientasi Global, Berwawasan Lingkungan dan Paling Bersahabat".

Visi 2005-2025 ini telah pula diakomodasi oleh visi pemerintah Kota Makassar 2014-2019, di era kepimimpinan Danny Pomanto, yaitu "Makassar Kota dunia, dengan upaya pengembangan Niaga dan Pendidikan yang Bermartabat dan Manusiawi”. visi-misi 2014-2019 ini oleh Danny perlu diajukan untuk menjamin konsistensi pembangunan dan perubahan yang berkelanjutan, melalui visi lima tahun, yakni "Makassar Kota Dunia Berlandaskan Kearifan Lokal”. Selain itu, juga itu di pertimbangkan isu dan kecenderungan strategis dalam jangka menengah yang telah di analisis dan menghasilkan faktor kecil keberhasilan, yakni:

a. Terbangunnya kerjasama konstruktif antara pemerintah dan masyarakat. b. Terjaminnya konsistensi kebijakan pemerintah.

c. Terpeliharanya komitmen bersama seluruh pemangku kepentingan dalam mewujudkan kepemerintahan yang baik.

d. Ketersediaan anggaran serta sarana dan prasarana yang memadai.

e. Ketersediaan sumber daya manusia yang berkualitas serta amanah terhadap nilai-nilai ketimuran/budaya lokal.

f. Situs keamanan dan ketertiban masyarakat yang kondusif dan berkesinambungan.

g. Berperannya unit-unit organisasi pemerintahan kota (SKPD) dalam penyelenggaraan pemerintah, pembangunan dan pembinaan kemasyarakatan.

Pendekatan ini dimaksudkan untuk mengantisipasi perkembangan dan perubahan yang akan terjadi, sehingga persoalan-persoalan yang di perkirakan timbul sudah dapat di pertimbangkan penangananya secara lebih dini. Bersamaan dengan itu, dipertimbangkan pula harapan-harapan yang berkembang di tengah masyarakat tentang wujud Kota Makassar dalam jangka menengah dan kedepan.

Visi Misi 2014-2018 ini tidak dapat dilepaskan dari kenangan mereka terhadap kejayaan Makassar masa lalu, kondisi masyarkat dan potensi sumber daya alam Kota Makassar. Oleh karena itu, ditahun 2014 untuk membangun Kota Makassar diperlukan pendekatan tersendiri, yakni pendekatan "pembangunan berkarakter". Pembangunan berkarakter dalam konteks ini berciri pembangunan yang bisa di pahami, punya bahasa publik, dapat dibaca, dapat dilakukan dan sesuatu yang berbeda antara satu dengan yang ada pada umumnya.

Visi "Makassar Kota Dunia Berlandaskan Kearifan Lokal” ini terinspirasi dari dua hal yang mendasar; Awal, jiwa dan semangat untuk memacu perkembangan Makassar agar lebih maju, terkemuka dan dapat menjadi kota yang diperhitungkan dalam pergaulan regional, nasional dan global. Kedua, jiwa dan semangat untuk tetap memelihara kekayaan kultural dan kejayaan Makassar yang telah di bangun sebelumnya, ditandai dengan keterbukaan untuk menerima perubahan dan perkembangan, tidak meninggalkan nilai-nilai yang menjadi warisan sejarah masa lalu 
Selanjutnya penjabaran dari visi tersebut, akan dilakukan melalui 5 (lima) Misi sebagai berikut;

1) Mewujudkan warga kota yang sehat, cerdas, produktif, berdaya saing dan bermartabat;

2) Mewujudkan ruang kota yang ramah lingkungan;

3) Mewujudkan peran strategis Makassar dalam perekonomian domestik dan internasional;

4) Mewujudkan tata kelola kepemerintahan yang baik dan berkualitas;

5) Mewujudkan kehidupan warga kota yang harmoni, dinamis, demokratis dan taat hukum.

a. Bidang Pendidikan

Pembangunan pada sektor pendidikan bukan hanya peningkatan dari segi sarana dan prasarana, namun pendidikan juga mengarah pada pengubahan mindset masyarakat mengenai pentingnya pendidikan. (Pratiwi, A. L. (2015). Tujuan dari pembangunan pendidikan adalah menghasilkan manusia yang menyadari bahwa dirinya merupakan bagian yang turut bertanggung jawab dalam mingkatkan kualitas tatanannya. Untuk itu pendidikan berperan dalam mempercepat kemandirian masyarakat dengan meningkatkan sumber daya. Karena hanya dengan daya manusia yang unggul, terampil dan mandiri maka kesejahteraan masyarakat bisa terwujud dangan baik.

Upaya pemerintah juga dilihat dari bagaimana usahanya untuk melestarikan penggunaan aksara lontara dalam kehidupan sehari-hari. Peninggalan leluhur ini harus dilestarikan sebagai bentuk penghargaan terhadap usaha nenek moyang. Hal ini menjadi perhatian ditengah perkembangan modernitas masyarakat Kota Makassar sebagai sebuah Kota modern yang metropolis. Upaya tersebut tampak dengan cara menyertakan aksara lontara pada setiap papan nama jalan di seluruh Kota Makassar. Kini ketika menelusuri setiap jalan yang ada di Kota Makassar maka akan ditemukan papan nama jalan yang juga tercantum aksara lontara didalamnya. Hal ini juga dilkaukan sebagai wujud pelestarian warisan lokal masa lampau. (Bahrul Ulum Ilham, 2007)

b. Bidang Kesehatan

Dalam rangka peningkatan dan pemerataan pelayanan kesehatan, pemerintah Kota Makassar sejak tahun 2014 sampai dengan tahun 2019 telah melalukan pelayanan kesehatan gratis pada seluruh puskesmas yang ada di Kota Makassar. Pelayanan inipun merata keseluruh masyarakat tanpa membedakan kondisi ekonomi. Artinya, baik warga yang kaya maupun yang miskin memiliki hak yang sama dalam pelayanan kesehatan. Senada dengan yang dikatakan Danny Pomanto: "Untuk meningkatkan kualitas kesehatan masyarakat maka kami gratiskan semua tidak pandang miskin atau kaya." (Pomanto, 2019)

Terkait dengan kesehatan gratis tersedia 1.034 sarana pelayanan kesehatan bagi warga Kota Makassar yang terdiri dari 1 unit rumah sakit umum daerah daya, 8 unit puskesmas rawat inap, 35 unit puskesmas non rawat inap, 40 unit puskesmas pembantu dan 979 posyandu yangdidukung oleh 207 orang tenaga medis, para medis 872 orang, non medis 137 orang, tenaga tekhnis kesehatan lainnya 53 orang dan tenaga non kesehatan 44 orang. Sedangkan masyarakat pulau di sediakan puskesmas keliling laut 2 buah yang siap memberikan pelayanan dan mengatasi berbagai keluhan kesehatan masyarakat pulau. Khusus penanggulangan HIV/AIDS disediakan pula 4 puskesmas percontohan metode yaitu puskesmas Kassi-Kassi, Jumpandang Baru, Jongaya dan Makkasau dari 24 keseluruhan yang ada di indonesia dan siap memberikan pelayanan dan rujukan bagi penderita HIV/AIDS dan penyalahgunaan narkoba (NAPZA).

Selain itu di Kota Makassar telah dicanangkan Makassar bebas nyamuk yang bekerjasama dengan media cetak berita Kota Makassar. Untuk meningkatkan kualitas dan standarisasi pelayanan puskesmas tahun 2018 ini telah ada 13 puskesmas yang mendapatkan sertifikat sistem manejemen mutu sesuai standar ISO 9001:2008 diantaranya Puskesmas BaraBaraya, Batua, Jongaya, Kassi-Kassi, Sudiang Raya, Makkasau, Jumpandang Baru, Tamalaanrea, Mamajang Dahlia, Malimongan Baru, Pattingalloang dan Tarakan tahun 2017.

Gebrakan pemerintah kota Danny Pomanto melalui pelayanan kesehatan gratis menghasilkan perubahan yang signifikan terhadap kinerja dan pelayanan puskesmas di Makassar. Tak heran jika kemudian puskesmas kini benar-benar menjadi layanan kesehatan andalan warga Kota Makassar. Kalau sebelumnya hanya warga 
miskin, kini warga golongan mampu juga sudah datang berobatdi puskesmas jika mereka sakit.

c. Bidang Tata kota dan Kebersihan

Salah satu bentuk keseriusan dari Pemerintah Kota Makassar untuk Mendukung MTR adalah membentuk Unit Pelaksana Tugas Daerah (UPTD) Bank Sampah Pusat (BSP) dan Bank Sampah Unit (BSU). Bank Sampah adalah suatu tempat yang digunakan untuk mengumpulkan sampah yang sudah dipilah-pilah. Hasil dari pengumpulan sampah yang sudah dipilah akan disetorkan ke vendor pengepul sampah. Tujuan Dari Bank Sampah adalah untuk menyadarkan masyarakat akan lingkungan yang sehat, rapi, dan bersih. Bank sampah juga didirikan untuk mengubah sampah menjadi sesuatu yang lebih berguna dalam masyarakat, misalnya untuk kerajinan dan pupuk yang memiliki nilai ekonomis.

Hasil penelitian bahwa

Sesungguhnya Bank Sampah (BS) di Kota Makassar sudah ada sejak tahun 2012, akan tetapi proses pelaksanannya tidak berjalan secara maksimal. Di tahun 2014 program ini kembali di hidupkan dengan membentuk UPTD Bank Sampah Pusat yang berlokasi di Daerah Toddopuli bagian Timur. Program ini sangat didukung oleh Bapak Walikota Makassar sehingga mengeluarkan sebuah tagline yaitu TANGKASARONG" (Tabungan Bank Sampah Anak Lorong). Proses pelakasanaan Pengelolaan Bank Sampah yaitu warga yang ingin bergabung sebagai nasabah dari Bank Sampah Unit.

Salah satu contoh kesuksesan progran pengelolaan sampah yang di kerjakan oleh Seorang dokter bernama Gamal Albinsaid dari Kota Malang mengagas sebuah asuransi kesehatan yang membayarnya dengan sampah. Asuransai kesehatan "sampah" ini dapat membantu masyarakat untuk mendapatkan layanan kesehatan tanpa harus membayar dengan uang melainkan dengan sampah.

Kesuksesan yang di lakukan oleh Dokter gamal bersama rekannya tidak menurunkan optimisme Program BS dari Pemerintah Kota Makassar. Saat ini PEMKOT Makassar bersama PT. Unilever cabang Makassar bekerjasama melakukan pengembangan program BS. Jika sebelumnya, sampah yang dikumpulkan masyarakat dapat ditukarkan dengan beras ataupun uang dalam bentuk tabungan, kini sampah yang telah dipilah dan dikumpulkan di BS dapat ditukarkan dengan produk Unilever seperti sabun, deterjen, margarin, dan kebutuhan rumah tangga lainnya. Bank Sampah sebagai pendukung program MTR tidak hanya efektif memberikan edukasi kepada masyarakat dalam menjaga kebersihan dan memanfaatkan sampah menjadi barang ekonomis namun juga berdampak pada peningkatan positif interaksi sosial masyarakat. Bank sampah sebagai pendukung Program (MTR) tidak hanya efektif memberikan edukasi kepada masyarakat dalam menjaga kebersihan dan memanfaatkan sampah menjadi barang ekonomis namun juga berdampak pada peningkatan positif interaksi sosial masyarakat.

Melihat berbagai fungsi dari Bank Sampah sehingga dalam rapat Koordinasi Nasional (Rakornas) Pengelolaan Sampah dan Adipura 2016 yang berlangsung Senin (1/2) di Jakarta staf Ahli Menteri LHK Hermawan Kertajaya menyatakan Kota Makassar sangat pantas dijadikan sebagai pilot Project Nasional Pengelolaan Bank Sampah. Kemampuan Pemerintah Kota menggugah warga kota untuk terlibat aktif membentuk dan mengelola bank Sampah sangat pantas diacungi jempol. Program Lorong Garden merupakan program strategis Pemkot dalam menata dan memberdayakan masyarakat Makassar. Lorong garden, salah satu bagian dari Program Andalan Walikota Makassar Bapak Danny Pomanto yakni "Makassar Tidak Rantasa” (MTR). Program Lorong garden adalah bagian program MTR yang di gaungkan disetiap kelurahan dan kecamatan di Kota Makassar.

\section{d. Bidang Ekonomi}

Di bidang pembangunan daerah, maka pelaksanaan pembangunan kota Makassar pada periode 2014-2018 itu dilaksanakan menurut bidang atau sektor pembangunan, , pertambangan, industri pengolahan, industry kreatif, listrik gas dan air, bangunan, perdagangan restoran dan hotel, angkutan dan komunikasi, keuangan, persewaan dan jasa perusahaan, dan jasa.

Pada pemerintahan Danny sebagai Walikota Makassar, produksi pendapatan regional bruto sesuai dengan harga yang berlaku pada tahun 2016 sebesar Rp. 50,23 Juta lebih dan pada tahun 2017 meningkat menjadi Rp. 58,54 Trilyun lebih. (Makassar, 2018) Selain itu, perkembangan 
ekonomi Kota Makassar juga dipengaruhi oleh dunia perbankan. Hal ini bisa dilihat dari jumlah pinjaman yang meningkat. Sejak tahun 2016 jumlah pinjaman tercatat sebesar Rp. 40,00 juta, ini meningkat pada tahun 2017 menjadi Rp. 43, 28 juta.

Guna mengukur tingkat kemakmuran masyarakat Kota Makassar, indikator yang digunakan adalah angka perkapita bruto. Pendapat perkapita bruto menunjukkan perkembangan PDRB perkapita yang meningkat dari Rp. 37,26 juta lebih ditahun 2012, menjadi Rp. 42,64 juta lebih ditahun 2018. Dari semua itu struktur ekonomi Kota Makassar masih dipengaruhi oleh sektor perdagangan, restoran, dan hotel. (Statistik, 2018)

Struktur ekonomi masyarakat di Kota Makassar tahun 2014-2018 terjadi pasang surut. Sektor pertanian misalnya, pada tahun 2014 presentasinya hanya $0,85 \%$ bahkan terus menurun menjadi $0,74 \%$ pada tahun 2011 dan menurun lagi mencapai $0,55 \%$ pada tahun 2018, hal ini membuktikan bahwa sektor pertanian bukanlah hal yang menjadi ciri dari masyarakat Kota Makassar. Maksudnya adalah sektor pertanian dianggap kurang cocok dengan karakter masyarakat Kota Makassar, sehingga banyak area pertanian yang dialihkan menjadi sektor-sektor lain misalnya saja pembangunan perumahan dan fasilitas berupa kantor dan sebagainya. Adapun di sektor pertambangan dan penggalian, tidak mengalami perubahan dari tahun 2014 hingga 2018 hanya mencapai angka 0,01\%. Ini menandakan bahwa kurangnya lokasi pertambangan dan pernggalian yang ada di Kota Makassar. Di sektor industri pengolahan juga mengalami penurunan selama tahun 2014 hingga 2018. Adapula beberapa sektor lain yang juga mengalami penurunan seperti listrik gas dan air, angkutan dan komunikasi. Adapula beberapa sektor yang pada awalnya meningkat tetapi pada tahun berikutnya mengalami penurunan misalnya pada sektor keuangan, persewaan dan jasa perusahaan dimana pada tahun 2014 angkanya mencapai $10,58 \%$ meningkat menjadi $10,25 \%$ pada tahun 2011 dan kembali meningkat ke angka $11,61 \%$ pada tahun 2018. Selanjutnya ada beberapa sektor yang mengalami peningkatan dari tahun ketahun seperti perdangangan restoran dan hotel yang menembus angka 29,60\% pada tahun 2018 dimana pada tahun 2014 hanya pada angka 29,14\%. Selebihnya, ada beberapa sektor yang juga mengalami penurunan seperti yang terjadi pada sektor pertanian dan angkutan dan komunikasi. Adapun di sektor jasa dari tahun 2014 hingga 2018 mengalami pertumbuhan meskipun tidak terlalu signitifikan. (Makassar P. K., 2019)

e. Bidang Sosial

1) Pelayanan Administrasi

Pada masa pemerintahan Danny Pomanto hal yang juga menjadi perhatian dari Danny adalah perbaikan pelayanan administrasi masyarakat. Jika pada masa pemerintah Sebelumnya telah ada pembebasan biaya penerbitan akta kelahiran, maka pada pemerintahan Danny Pomanto hal ini ditambah dengan pembebasan biaya penerbitan kartu tanda penduduk (KTP), dan kartu keluarga (KK), dan perizinan mendirikan bangunan atau IMB. Selain itu, Kota Makassar yang dihuni oleh beberapa kelompok masyarakat, tidak jarang terlibat pertikaian yang terkadang berujung pada pertumpahan darah. Untuk mengatasi hal tersebut, Walikota Danny Pomanto juga berupaya untuk mengatasi hal itu dengan jalan turun langsung kelapangan guna mendamaikan pihak yang bertikai. Hal ini juga sebagai imbas dari adanya pemukiman kumuh yang banyak menjamur di Kota Makassar.

2) Bantuan Hukum

Selama ini masyarakat bawah selalu berada di posisi yang kurang menguntungkan dalam hukum. Kadangkala mereka sebenarnya berada di pihak yang benar ketika sedang menghadapi sebuah kasus hukum, tetapi kemudian terkalahkan hanya karena persoalan sepele. Mereka tak punya kemampuan untuk mempertahankan kebenaran yang ada pada mereka karena dikalahkan kemampuan argumen dari lawan sengketa mereka. Walikota Danny menyadari hal itu sebagai sebuah ketidak adilan. Oleh karena itu, maka program pemberian hukum gratis diluncurkan oleh pemerintahan Kota Makassar dibawah kepemimpinan Danny Pomanto pada September 2014.

Program ini adalah program terobosan cerdas dari Danny Pomanto. Hal ini disebabkan, karena dibandingkan dengan program lainnya dalam IASmo bebas. Bantuan hukum gratis ini masih terbilang baru. Bahkan belum pernah diperkenalkan di daerah lain. Danny menyatakan 
bahwa program ini memang harus dihadirkan melihat kompleksitas masalah di Makassar.

Untuk pelayanan bantuan hukum gratis ini sendiri pemerintah Kota Makassar tak membuat payung dalam bantuan peraturan daerah (PERDA) seperti program lainnya dalam peraturan pemerintah kota yang saat ini telah diterbitkan dengan lewat peraturan walikota nomor 63 tahun 2014 tentang pelayanan bantuan hukum pendudukan tidak mampu. (Ferawati, F. (2016).

Untuk mendapatkan pelayanan bantuan hukum gratis ini, warga memang mesti harus mengurus beberapa proses administratif yang berbelit. Namun itu ditempuh agar warga yang berprakara nanti bisa mendapatkan hasil yang terbaik. Selain itu, pemkot ingin memastikan bahwa yang mendapatkan bantuan hukum itu adalah warga yang memang membutuhkan. Penduduk yang membutuhkan pelayanan bantuan hukum harus bermohon ke bagian hukum pemkot Makassar secara lisan dan tertulis. Kemudian melampirkan identitas kependudukan yang sah, dan uraian atau penjelasan singkat mengenai masalah hukum yang dimohonkan. Selanjutnya melampirkan surat keterangan tidak mampu dari pejabat berwenang seperti RT, RW, dan Askeskin. Masyarakat yang memohon pelayanan bantuan hukum hanya diberi waktu selama tujuh hari, dan paling lama 15 hari kerja semua kekurangan persyaratan sudah harus dipenuhi.

\section{E. Kesimpulan}

Kebijakan-kebijakan yang ditempuh oleh Danny Pomanto meliputi kebijakan di bidang pendidikan, kesehatan, pembangunan infrastruktur, kebersihan dan penataan kota, ekonomi, sosial dan agama. Pemerintah kota melakukan pembenahan fasilitas sekolah yang ada baik ditingkat SD, SMP, SMA. Selain itu, untuk menunjang kemampuan intelektual masyarakat Kota Makassar, pendirian taman baca dan pengerahan perpustakaan keliling. Tercatat ada 14 taman baca yang didirikan. Selanjutnya taman baca tersebut bertambah jumlahnya melalui partisipasi masyarakat. Ada juga pemberian subsidi kepada beberapa sekolah yang memenuhi syarat berdasarkan data dari nasional. Di bidang kesehatan dilakukan perbaikan kualitas pelayanan kepada masyarakat dengan adanya pembenahan puskemas dan penggratisan pelayanan kesehatan pada puskesmas untuk setiap golongan masyarakat. Di bidang pembangunan infrastruktur, pada periode pertama dilakukan program revitalisasi Pembenahan Lorong-lorong dan, pembangunan rusunawa, dan penyelesaian pembangunan menara kantor walikota. Di bidang Ekonomi perbaikan ekonomi dijalankan melalui upaya pengembangan pelabuhan dan pengembangan kawasan industri yakni Kawasan Industri Makassar (KIMA).

\section{Daftar pustaka}

Bahrul Ulum Ilham, D. (2007). Biduk Belum Berlabuh 400 Tahun Nafas Kota Makassar. Makassar: Humas Pemerntah Kota Makassar.

Ferawati, F. (2016). Luwu pada Masa

Pemerintahan H. Basmin Mattayang

Periode (2004-2009). Jurnal Pattingalloang, 3(4), 124-136.

Hamid, M. S. (2011). Pengantar Ilmu Sejarah. Yogyakarta: Ombak.

Haniah, B. U. (2011). Geliat Makassar Menuju Kota Dunia . Makassar: Humas Pemkot Makassar.

Idrus, N. (2005). Menguak Belantara Makassar. Makassar: Geo Medina Dinamika.

Kusuma, B. a. (2018). danny pomanto anak guru jadi walikota. Makassar: badan perpustakaan dan arsip daerah.

Makassar, P. (2018). Laporan Keterangan Pertanggung Jawaban Walikota Makassar Tahun Anggaran 2018. Makassar: Pemkot Makassar.

Makassar, P. K. (2019). Laporan Keterangan Pertanngung Jawaban (LKPj) Akhir Masa Jabatan (AMJ) Walikota Makassar tahun 204-2014. Makassar: Pemkot Makassar.

Makasssar, R. P. (2015). Patent No. 14. Makassar.

Pomanto, D. (2019, Mei Kamis). Wawancara.

Pratiwi, A. L. (2015). Megawati Soekarnoputri Presiden Wanita di Indonesia (2001-2004). Jurnal Pattingalloang, 2(1), 8-14.

Sjamsuddin, H. (2012). Metodologi Sejarah. Yogyakarta: Ombak. 
Statistik, B. P. (2018). Data BPS Kota Makassar . Makassar: Pemerintah Kota Makassar.

Temmanengnga, G. H. (2014). Komunikasi Birokrasi dalam menunjukkan 8 jalan masa depan. In Book. Makassar: Pustaka Celebes.
Temmanengnga, M. G. (2014). Komunikasi Birokrasi dalam menunjukkan 8 jalan masa depan. Makassar: Pustaka Celebes. 